\title{
Financial De-Dollarization: A Global Perspective and the Peruvian Experience
}




\title{
WP/16/97
}

\section{IMF Working Paper}

\section{Financial De-Dollarization: A Global Perspective and the Peruvian Experience}

\author{
by Luis A.V. Catão and Marco E. Terrones
}

IMF Working Papers describe research in progress by the author(s) and are published to elicit comments and to encourage debate. The views expressed in IMF Working Papers are those of the author(s) and do not necessarily represent the views of the IMF, its Executive Board, or IMF management.

$$
\text { I N T E R N A T I O N A L M O N E T A R Y F U N D }
$$




\section{IMF Working Paper}

Research Department

Financial De-Dollarization: A Global Perspective and the Peruvian Experience

Prepared by Luis A.V. Catão and Marco E. Terrones ${ }^{1}$

Authorized for distribution by Oya Celasun

April 2016

IMF Working Papers describe research in progress by the author(s) and are published to elicit comments and to encourage debate. The views expressed in IMF Working Papers are those of the author(s) and do not necessarily represent the views of the IMF, its Executive Board, or IMF management.

\section{Abstract}

We re-appraise the cross-country evidence on the dollarization of financial systems in emerging market economies. Amidst striking heterogeneity of patterns across regions, we identify a broad global trend towards financial sector de-dollarization from the early 2000 s to the eve of the global financial crisis of 2008-09. Since then, de-dollarization has broadly stalled or even reversed in many economies. Yet a few of them have continued to de-dollarize. This suggests that domestic factors are also important and interact with global factors. To gain insight into such an interaction, we examine the experience of Peru since the early 1990s and find that low global interest rates, low global risk-aversion, and high commodity prices have fostered de-dollarization. Domestic macro-prudential measures that raise the relative cost of domestic dollar loans and the introduction and adherence to inflation targeting have also been key.

JEL Classification Numbers: E44, E50, G20, G21.

Keywords: Dollarization, Currrency Substitution, Monetary Policy, Emerging Markets.

Author's E-Mail Address: 1catao@imf.org; mterrones@imf.org.

\footnotetext{
${ }^{1}$ We thank Adrian Armas, Marcello Estevão, Gustavo Yamada, Diego Winkelried, and seminar participants at the Universidad del Pacífico for comments on an earlier draft, as well as Maria Jovanovic for editorial assistance. The usual caveats apply.
} 


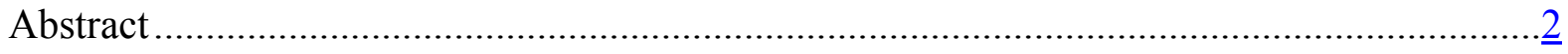

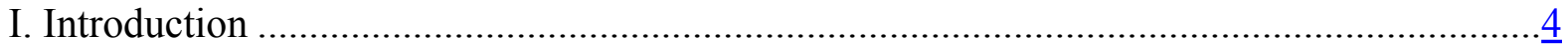

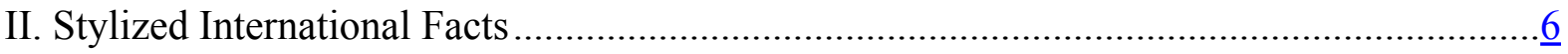

III. The Analytics of the De-dollarization.............................................................

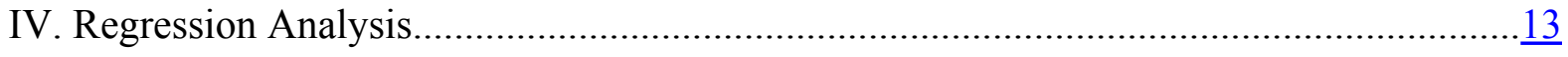

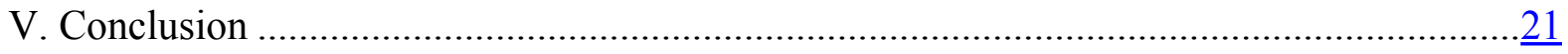

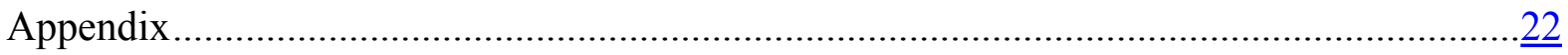

A. List of EMEs in the Cross-Country Sample.......................................................

B. Data Sources of the Peruvian Database........................................................

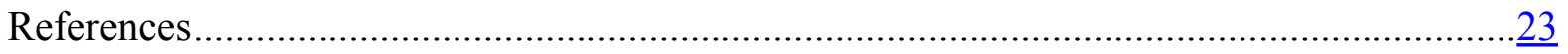

\section{Tables}

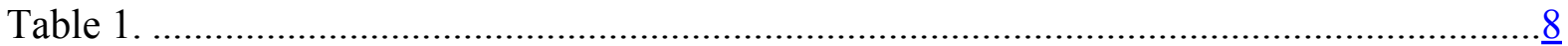

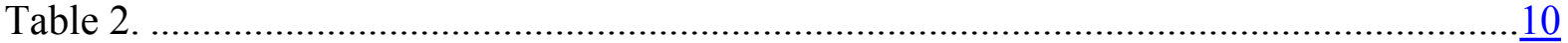

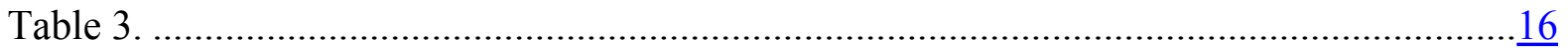

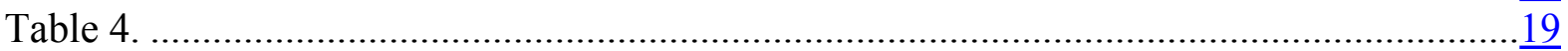

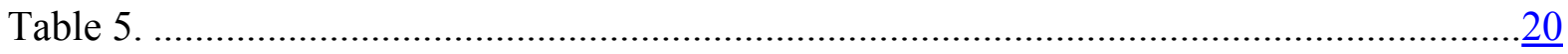

\section{Figures}

Figure 1. Deposit Dollarization in EMEs ......................................................................... 7

Figure 2. EMEs: Recent Trends in Deposit Dollarization ................................................ $\frac{9}{4}$

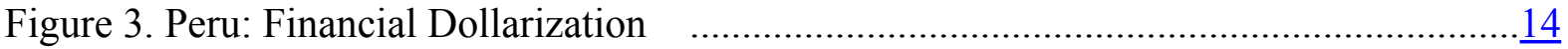

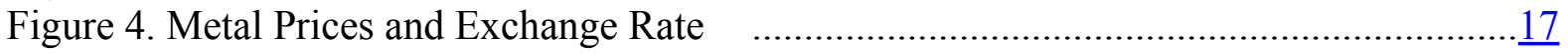




\section{INTRODUCTION}

Dollarization has been a buzzword for weak macroeconomic fundamentals in many emerging market economies (EMEs) over the past 40 years. It started off as a "pure" currency substitution phenomenon in the 1970s in Latin America, where local currencies were often debased of their traditional roles by high- and hyper-inflation bouts, inducing households and firms to substitute foreign currency (usually the US dollar) for domestic currency holdings. ${ }^{2}$ Such a currency substitution process has been typically gradual, with domestic currencies losing first their medium of exchange function followed by the loss of their unit of account function, particularly for major-item transactions like real estate, machinery and equipment, etc. ${ }^{3}$ Local currency transactions, however, never disappeared in most cases, giving rise to dual currency economies in much of the region.

From being a pure currency substitution phenomenon, dollarization has moved on to become a more generalized feature of financial sector intermediation, as banks themselves started taking deposits and lending in two or more currencies. ${ }^{4}$ This asset substitution form of dollarization is associated with the local currency losing its store of value function due to its negative returns and the introduction of financial contracts in foreign currencies. By the early 1990s, the banking systems in many emerging market economies routinely built nontrivial assets and liabilities positions denominated in dollars. This process - known as financial dollarization - has mushroomed in the 1990s through the early 2000s in distinct regions, posing important financial stability challenges to policymakers. By its own nature, a dollarized financial system involves important risks, including the possibility of large mismatches between the share of dollar-denominated liabilities and the share of dollardenominated assets, leading to large income losses to banks when exchange rates fluctuate as well as the possibility a run on less-than-fully backed dollar-deposits, owing to fractional reserve banking. These risks can trigger a generalized bank run under not-so-uncommon preconditions (Rajan and Tokatlidis, 2005). Indeed, the financial crises that hit many dollarized

\footnotetext{
${ }^{2}$ Large and unsustainable fiscal imbalances were often behind these episodes of high and hyper-inflation (Catão and Terrones, 2005). This suggests that fiscal profligacy might have been an important driver of currency substitution and dollarization, more broadly.

${ }^{3}$ As noted by Calvo and Végh, 1996, there is no consensus about the definitions of "currency substitution" and "dollarization." They denote "currency substitution" as the swapping of a domestic by a foreign currency in its medium of exchange function; likewise, they define "dollarization" as the displacement of a domestic by a foreign currency in one or more of its three functions - unit of account, medium of exchange, or store of value.

${ }^{4}$ Banks were often allowed to accept dollar deposits, and make dollar loans, in an attempt to enhance financial intermediation in a high inflation environment and/or preserve international reserves following several years of balance of payments problems.
} 
emerging market economies in the 1990s (such as Turkey in 1994, Argentina in 1995, Russia in 1998) and early 2000s (Argentina in 2001) involved the materialization of these risks. ${ }^{5}$

While the currency substitution phenomenon has been widely studied, the dynamics of financial dollarization is less well understood. ${ }^{6}$ One strand of the literature has sought to explain it by models featuring financial frictions such as asymmetric liquidation costs and imperfect information (Broda and Levy-Yeyati, 2006; Rapoport, 2009). Asset dollarization has also been studied as the result of institutional weaknesses (Rajan and Tokatlidis, 2005) and from the perspective of a non-competitive banking industry operating in two currencies (Catão and Terrones, 2000). Others have studied the determinants of asset dollarization utilizing reduced-form panel regression models (De Nicólo et al. 2003; Levy-Yeyati, 2006; Honohan, 2007; Antinolfi et al., 2007) or vector autoregression models (García-Escribano and Sosa, 2011).

This paper documents recent financial dollarization trends in the emerging market economies focusing, in particular, on the de-dollarization of highly dollarized economies, such as Peru. We examine three questions. How homogenous have been the patterns of financial dollarization and de-dollarization across the emerging market economies over the past fifteen years? What factors have contributed to the recent de-dollarization of some highly dollarized economies such as Peru? What are the lessons of the recent financial dedollarization experience going forward?

As a first step towards addressing these questions, we begin by documenting trends in financial dollarization in the emerging market economies since 2000. A main stylized fact emerging from this analysis is that most EMEs have de-dollarized. Together with this important trend, dollarization persistence - a much emphasized empirical regularity in earlier work - has been broadly on the wane in most highly dollarized EMEs. While this by itself indicates that global factors have been an important driver of de-dollarization, the speed of this process has been far from homogeneous. This suggests that country-specific factorspotentially related to the mitigation of financial frictions featured in earlier models of dollarization and/or macroeconomic and regulatory policy factors - have also been important. If so, standard panel regressions on the determinants of financial dollarization, which have been the workhorse of previous empirical work, may be less helpful to determine the main drivers of de-dollarization. We follow this lead by zooming in on the most striking and arguably successful experience with de-dollarizing from very high and persistent levels - namely, the experience of Peru in recent years.

\footnotetext{
${ }^{5}$ See, for instance, Gulde, et al., 2004.

${ }^{6}$ Currency substitution has been studied by, among others, Guidotti and Rodriguez, 1992, Rojas-Suarez, 1992 , and Savastano, 1996.
} 
As in previous studies, we take an aggregate perspective to examine the Peruvian experience but — relative to some of the literature - we do subject our reduced-form estimates to a greater variety of controls and robustness checks with a view to get down to the most essential drivers of dollarization and de-dollarization. The broad picture emerging thereof is that global factors have been indeed important but monetary and macro-prudential policiesnotably the country's move to an inflation targeting regime and the use of macro-prudential measures - have also been crucial. To the extent that financial sector de-dollarization is desirable, this raises the question of which policy choices and instruments are preferable to achieve this process. While the adoption of an inflation targeting regime is generally nondistortionary, the introduction of some prudential measures, while useful in the short-run, can have distortionary effects, particularly if not properly designed. As such, a de-dollarization process that is only based on the latter measures is more likely to hamper financial intermediation and growth.

The plan of the paper is as follows. Section I reviews the international experience with financial sector dollarization from 2000 to early 2015 and highlight pertinent stylized facts. Section 2 briefly reviews the main determinants of financial dollarization (dedollarization). In light of this review, Section 3 provides econometric evidence for Peru. Section 4 concludes with a brief discussion of policy implications.

\section{STYLIZED InTERNATIONAL FACTS}

The most widely used measure of financial dollarization is the stock of deposits in the banking system that is denominated in foreign currency-meaning the US dollar and/or the euro - as a share of total deposits. We construct this metric with data from the Standardized Report Form (SRF) adopted by many countries to submit monetary sector information to the IMF. ${ }^{7}$ Our deposit dollarization dataset comprises quarterly data for 28 emerging market economies over 2000:Q1-2015:Q1 (see Appendix, part A).

We start by presenting the main statistical properties of financial dollarization. These include those that were previously identified but which our broader dataset corroborates.

- Fact 1: Financial dollarization varies significantly across emerging market economies.

Figure 1 shows the box plot distribution of deposit dollarization in distinct emerging market regions. First, emerging market economies as a whole are not highly dollarized: the median dollarization ratio for these economies is just over 17 percent. This suggests that local currency is the preferred store of value in these economies. There are, however, several

\footnotetext{
${ }^{7}$ The SRF allows for a common cross-country presentation of this data (i.e., by sectors, instruments, currencies, etc.) and in most cases data is available only since the year 2000. Data for Argentina and Peru, countries that are in process of adopting the SRF, has been obtained from the IFS.
} 
emerging market economies that are either semi-dollarized (dollarization ratio close to 50 percent) or highly dollarized (dollarization ratios higher than 50 percent), as suggested by the positively skewed distribution of the dollarization ratio around the median. Second, the emerging economies in Latin America and Europe - the later comprising almost exclusively formerly transition economies - are significantly more dollarized than those in Asia/rest of the world. Despite these relatively high levels of dollarization, the Latin American and European economies fall short of being semi-dollarized. ${ }^{8}$ As a group, the Latin American economies tend to be somewhat more dollarized than the European economies. Yet, there is much more dispersion in deposit dollarization in Latin America, and some of it reflects prohibition or severe legal restrictions to dollar accounts in some countries in the region, such as Brazil and Chile.

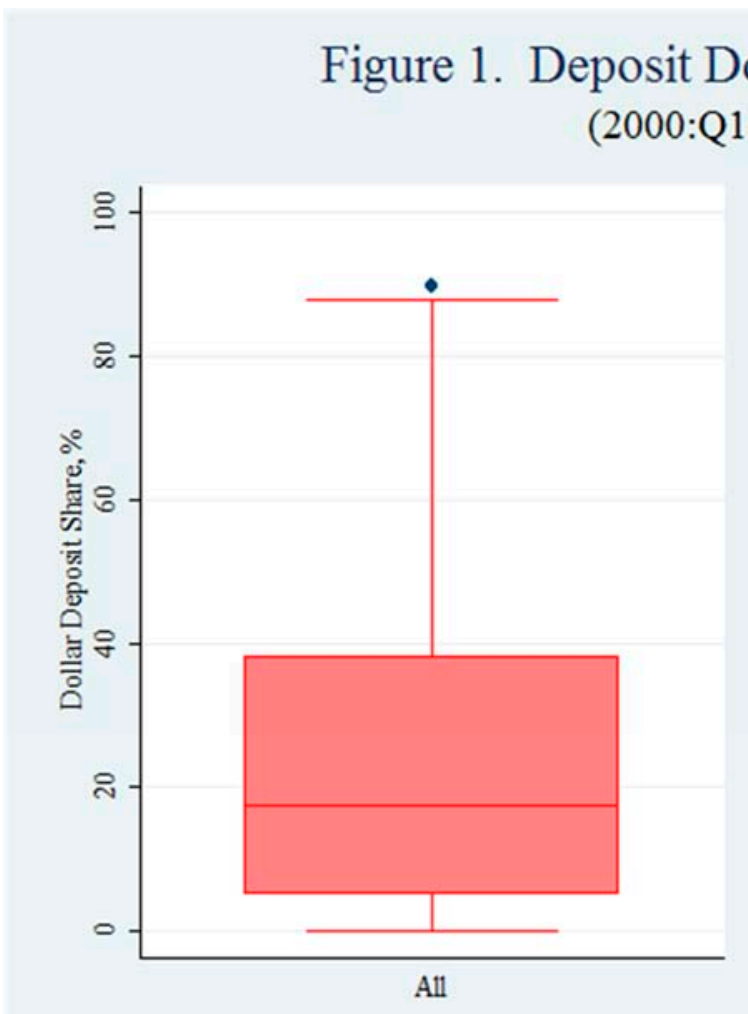

Note: Authors' calculations

- Fact 2: Financial dollarization is typically highly persistent.

We estimate the persistence of financial dollarization in our emerging market economies sample by using variations of the basic autoregressive process of the deposit dollarization ratio. Table 1 reports the results obtained from three estimators-pooled mean

\footnotetext{
${ }^{8}$ The 95 percent confidence interval for the median in Latin America and Europe are $[28.8,35.6]$ and $[27.0$, 34.5], respectively.
} 
regression, panel regression with FE, and panel least square dummy variable (LSDV). These results corroborate that financial dollarization in these economies is a highly persistent process - which means that dollarization tends to remain virtually unchanged over time. ${ }^{9}$ This might be a reflection of the presence of weak institutions, poor fiscal frameworks,

Table 1: Financial Dollarization Persistence

(2000:Q1-2015:Q1)

\begin{tabular}{lllll}
\hline & MG & FE & LSDV \\
\hline & & & & \\
Deposit dollarization ratio (lagged) & $0.925^{* * *}$ & $0.946^{* * *}$ & $0.974 * * *$ \\
& {$[0.00966]$} & {$[0.0163]$} & {$[0.00758]$} \\
& & & \\
\hline
\end{tabular}

Note: Dependent variable is the deposit dollarization ratio. Standard errors (SE) in brackets.

FE reports robust and clustered SE. Seasonal dummies are included as regressors.

* significant at the 10 percent level, ${ }^{* *}$ significant at the 5 percent level, *** significant at the 1 percent level.

nonexclusive credit contracts, and heterogeneous agents (see, for instance, Rappoport, 2009, Winkelried and Castillo, 2010, among others). As a result, there have been important doubts about policymakers' ability to de-dollarize their economies.

\section{- $\quad$ Fact 3: Financial de-dollarization can also be persistent.}

Figure 2, left panel, plots the evolution of mean deposit dollarization for all emerging market economies, as well as for the Latin America, European, and Asia/Rest regions. Two important stylized facts stand out. The first, already mentioned in the introduction, is that high levels of financial dollarization were pervasive by the early 2000 s, following its steep rise in many emerging markets during the 1990s. The second and novel feature worth highlighting is the significant decline in financial dollarization in several emerging Europe and Latin America economies in the years preceding the global financial crisis of 2007-08. Anticipating some of our later discussion, the 2000-07 period was marked by dramatic changes in monetary policy regimes in most of these economies, associated with the dissemination of inflation targeting regimes. ${ }^{10}$ At the same time many of these economies

\footnotetext{
${ }^{9}$ There is a large literature that has documented that financial dollarization in some emerging economies displays "hysteresis" - that is, it rises in periods of economic disarray but does not fall proportionately when the economy is stabilized.

${ }^{10}$ Just to cite a few adoptions, the Czech Republic was the first EM to introduce full-fledge inflation targeting in 1998. While Chile first introduced annual targets for inflation in 1991, a full-fledged IT framework has been in place only since 1999 after the relaxation of capital controls and elimination of exchange rate bands. Also in 1999 both Brazil and Poland introduced IT. In the 2000s, South Africa and Thailand introduced it in 2000, Korea, Hungary and Mexico in 2001, and Peru, the Philippines and Turkey in 2002. Among the most dollarized
} 
have become more integrated to the world economy increasing their sensitivity to international trade and finance developments. One important implication of this finding is that dollarization is persistent but not irreversible.

Figure 2. EMEs: Recent Trends in Deposit Dollarization
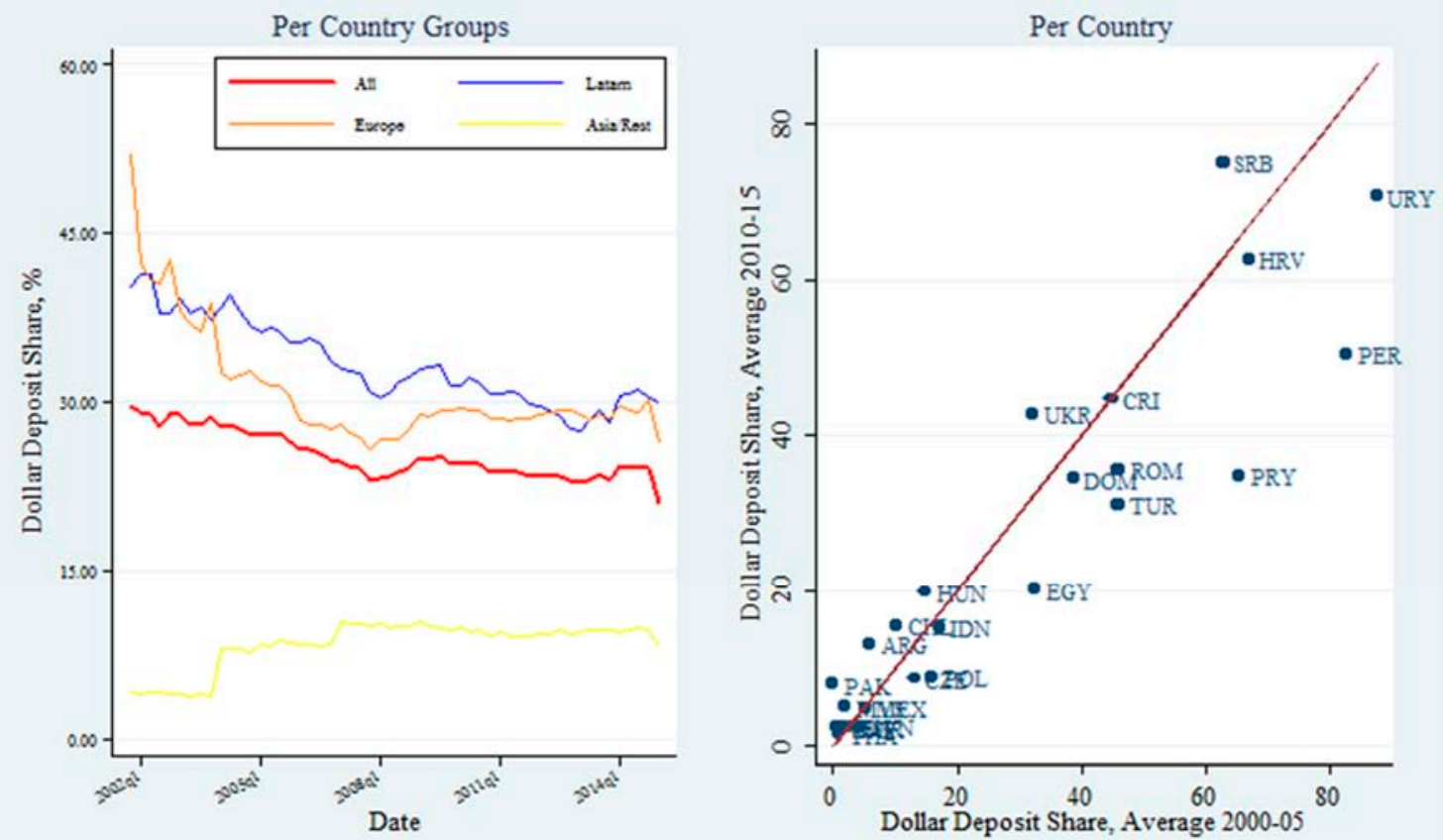

Source: Authors' calculations

- Fact 4: Financial de-dollarization has either partly reversed or stalled following the Global Financial Crisis (2007:Q3-2008:Q4).

The left panel of Figure 2 shows that de-dollarization has either stalled or been partly reversed in the emerging market economies since the Global Financial Crisis (GFC). At the regional level, the process of de-dollarization in emerging Europe and Latin America was mildly reversed in 2008-09. This reversal continued in emerging Europe during the European sovereign debt crisis of 2009-13, particularly in the former transition economies where countries like Serbia and Ukraine experienced a non-trivial increase in dollarization (see right panel of Figure 2). In contrast, Latin American economies continued to de-dollarize with the most dollarized economies in this region — namely Peru and, to lesser extent, Uruguayexperiencing substantive de-dollarization throughout 2015. This latter fact underscores the importance of country-specific factors in accounting for the pace of de-dollarization in recent

EMs, Uruguay introduced IT quite belatedly, in 2007, but started allowing for greater flotation of the exchange rate from 2003. See Mishkin and Schmidt-Hebbel, 2007, for further details and broader cross-country data. 
years. As discussed below, the Peruvian experience highlights the importance of both domestic and favorable external conditions.

Overall, the thrust of the emerging market experience underscores the importance of dollarization persistence, but also that this persistence is not uniform and unchangeable. In fact, as Table 2 estimates highlight, there has been a slight reduction in dollarization persistence after the Global Financial Crisis, albeit the change is not quite statistically significant at 5 percent. At any rate, the salient point in light of this evidence is that dollarization persistence is not synonymous of dollarization irreversibility: some highly dollarized countries have experienced remarkable de-dollarization in recent years.

Table 2. Financial Dollarization Persistence (2000:Q1-2015:Q1)

\begin{tabular}{lllrrr}
\hline Period & Regressor & & MG & FE & LSDV \\
\hline \multirow{2}{*}{ Pre-GFC } & Deposit dollarization ratio (lagged) & $0.837^{* * *}$ & $0.914^{* * *}$ & $0.977^{* * *}$ \\
& & & {$[0.0403]$} & {$[0.0374]$} & {$[0.0181]$} \\
Post-GFC & Deposit dollarization ratio & (lagged) & $0.810^{* * *}$ & $0.875^{* * *}$ & $0.964^{* * *}$ \\
& & & {$[0.0327]$} & {$[0.0277]$} & {$[0.0170]$}
\end{tabular}

Note: Dependent variable is the deposit dollarization ratio. Standard errors (SE) in brackets. FE reports robust and clustered SE. The Global Financial Crisis (GFC) covers the 2007:Q3-2008:Q4 period. Seasonal dummies are included as regressors.

* significant at the 10 percent level, ** significant at the 5 percent level, *** significant at the 1 percent level.

\section{The Analytics OF The De-Dollarization}

What could explain the de-dollarization in emerging markets between the early 2000s and the GFC and its stalling since then in many — but not all—countries? What explains the continuation of de-dollarization in some countries like Peru? In principle there are two sets of factors: the domestic or country-specific factors and the external or global factors.

Among the domestic factors, the existing literature highlights five factors. One is the adoption of inflation targeting (IT). ${ }^{11}$ Insofar as inflation targeting is seen to be a credible regime that delivers low and stable inflation, it helps strengthen the domestic currency as a store of value. One important potential drawback of inflation targeting in a highly dollarized economy is the possibility of financial instability resulting from exchange rate volatility, once monetary policy stops targeting the exchange rate. This could induce policymakers in these economies to display some "fear to float" (Calvo and Reinhart, 2002). As it turns out, however, exchange rate volatility in inflation targeters is not always higher than among non-

\footnotetext{
${ }^{11}$ As discussed in IMF (2005), inflation targeting differs from other monetary policy regimes in two main aspects: (1) the central bank commits to a numerical target for inflation-level or range; and (2) the inflation forecast over a given period is also the intermediate target for inflation.
} 
inflation targeters (Edwards, 2006). So, the adoption of inflation targeting in dollarized emerging economies is likely to help de-dollarization - a hypothesis that is tested in our econometric analysis below.

Second, macro-prudential policies - such as caps on loan to value ratios, capital requirements, higher provisions for dollar lending, etc.- - might also be expected to influence de-dollarization. Such instruments have been used extensively by policymakers in the emerging market economies and, in particular, among the most dollarized ones. Some of these policies have aimed at avoiding credit booms - that is, periods of excessive credit expansion that are often associated with financial crisis (Mendoza and Terrones, 2014) - as well as limiting the financial system exposure to large exchange rate movements. On the whole, one would expect that these policies discourage financial dollarization. ${ }^{12}$

Third, policymakers have often sought to discourage financial dollarization by directly or indirectly "taxing" dollar lending and dollar deposits. This can and has been done by differentiating and increasing reserve requirements (RR) in dollar denominated deposits relative to local currency denominated ones. ${ }^{13}$ Requiring banks to hold below-market interest rate bearing balances is equivalent to imposing a tax on these institutions in the amount equivalent to the forgone interest. By raising the marginal cost of dollar loans, one would expect to decrease dollarization. ${ }^{14}$ The net effect on loan dollarization, however, might depend on whether these requirements are also applied to net external borrowing by financial institutions. If this is not the case, higher reserve requirement on bank deposits may simply result in lower deposit dollarization but higher net foreign borrowing by banks. So, loan dollarization might be unaffected in the end.

Fourth, faster expected economic growth, by affecting the demand for credit and improving investment returns, could lead to an increase/decline in financial dollarization. There are two main channels through which faster expected growth could affect financial dollarization. One is through higher domestic investment, leading to higher demand for both dollar loans and local currency loans. To the extent that dollar loan demand has higher (lower) income elasticity than local currency loan demand, loan dollarization will increase

\footnotetext{
${ }^{12} \mathrm{We}$ are arguing here, however, that they are not necessarily welfare enhancing. For instance, while the shortrun effects of these measures on financial dollarization seem reasonably unambiguous, the effects on financial deepening and growth over the medium-term can be negative. A cost-benefit analysis of their overall effects is, however, beyond the scope of this paper.

${ }^{13}$ A similar effect obtains by reducing the remuneration on the RRs on dollar deposits held at the central bank viz. the RR on local currency deposits.

${ }^{14}$ This is particularly so in the absence of segmentation between the local currency and dollar loan markets and to the extent that local currency loans are easily collateralizable as dollar loans. Thus, the net effect of local currency-biased RR policies may be also hampered by such segmentation factors as well as by any positive effect of higher RRs on financial dis-intermediation - for example, by inducing domestic residents to borrow offshore.
} 
(decrease). The other channel is higher net capital inflows. By boosting the confidence of foreign investors in a country's economic potential, faster expected growth helps attract private capital flows. ${ }^{15}$ To the extent that the attendant U.S. dollar inflows are intermediated by banks, dollarization should increase.

Fifth, the demand for dollar loans and the demand for local currency loans are also influenced by the evolution of price of non-tradables vis-à-vis the tradables. An increase of the relative price of non-tradables to tradables often leads to an increase in local currency loan demand in detriment of dollar loan demand. There have been cases, however, whereby an increase in the relative price of non-tradables has led to an expansion in dollar loans to the non-tradable sector - mainly real estate. This has raised the risk of currency mismatch and financial sector vulnerability. What would be thus the effect of an improvement in the relative price of non-tradables on financial dollarization? In general, it is expected that the improvement in the relative price of non-tradables to tradables will lead to a reduction in financial credit dollarization.

Lastly, the financial dollarization ratio tends to rise when the exchange rate depreciates. This effect is merely due to direct valuation gains/losses - when the local currency depreciates, the share of dollar loans (deposits) on total loans (deposits) rise. This effect, which is considered mechanical by some, has manifested with a vengeance over the past few years as result of the strong - and then weak - dollar. As the bilateral exchange rate is an endogenous variable, we will utilize international commodity prices as a proxy for it as there is evidence of a strong negative association between these two variables. Thus, dollarization should fall when commodity prices rise, as the local currency will tend to appreciate, increasing the share of local currency deposits (and local currency loans) in total deposits (and total loans).

But dollarization and de-dollarization are also shaped by global factors, exogenous to small open emerging economies. A potentially important external driver is the world interest rate. By lowering the cost of U.S. dollar external funding, lower world interest rates encourage dollar-denominated offshore borrowing. To the extent that this can substitute dollar-denominated deposits, this would tend to reduce the deposit dollarization measure used in Figures 1 and 2. However, the net effect on both deposit and loan dollarization is ambiguous, depending on the initial level of dollarization of deposits and non-deposit dollar liabilities as well as on the marginal costs of administering dollars and local currency accounts. As discussed in Catão and Terrones (2000), this is because, at the optimal, banks will equate the marginal costs of each source of funding and the cost of each segment of the loan market. If the shares of dollar loans and deposits (as a percent of total loans and total deposits) are already high, banks will tend to benefit from the lower global interest rates to finance local currency loans and complement that financing with local currency deposits,

\footnotetext{
${ }^{15}$ This is consistent with evidence provided in Phillips et al (2013) and Lane and McQuade (2014) that higher growth forecasts raise net capital inflows and bank credit.
} 
crowding out dollar deposits. Conversely, if initial dollarization levels (i.e., before the decline in world interest rates) are low, then the net effect will be an unambiguous rise in dollar loans and a reduction in local currency deposits. In the case of a country like Peru, where initial dollarization levels are high, one might expect de-dollarization to take place; yet, the effect will be mediated by the degree of substitution between local currency and dollar deposits and local currency- and dollar-loans. Ultimately, the end effect will be an empirical matter.

Another important external factor is risk-aversion in financial markets. A classic effect of rising global risk aversion is a flight into safe haven currencies, and the U.S. dollar is typically a prime choice. The flight to safety effects observed during the global financial crisis is a case in point. ${ }^{16}$ An increase in global risk aversion is typically associated with more volatile asset prices in emerging market economies. As such, we should expect financial dollarization to rise in an EME as global risk aversion increases. A widely-used proxy for this effect is the implied volatility of S\&P 500 index options - the so-called "VIX" index. We will use this indicator to test whether dollarization responds to such a global risk aversion factor.

In what follows we bring these hypotheses to the data and gauge the extent to which they can explain financial dollarization and de-dollarization in Peru.

\section{REGRESSION ANALYSIS}

We now examine the statistical and economic significance of those potential driving forces using quarterly data for Peru between 1993:Q1 and 2014:Q4. This is the longest quarterly time series available to study dollarization in any country, giving us sufficient degrees of freedom to test the various hypotheses discussed and allowing us to subject our econometric specification to a wide variety of controls. Details and sources of the data utilized in this section are reported in the Appendix, part B.

To measure financial dollarization, we employ both the financial sector credit dollarization (i.e. the ratio of dollar-denominated loans to total loans) and deposit dollarization (defined as above). While there is evidence that these two measures of dollarization co-move closely quite often (see Catão and Terrones, 2000; Levy-Yeyati, 2005) - as FX risk hedging considerations would indicate - there may be levels and shift differences that warrant regressions for each of those two dollarization indicators (Figure 3). These shifts reflect the fact that the variables that determine the demand for credit can be

\footnotetext{
${ }^{16}$ There is evidence that uncertainty runs contrary to the business cycle (Bloom, Kose, and Terrones, 2011). That is, uncertainty is much lower during expansions than during recessions. There are two important channels through which uncertainty can have a negative effect on economic activity. On the demand side, when faced with high uncertainty, firms reduce investment and households postpone their consumption of durable goods. On the supply side, firms' cut their hiring plans as adjusting personnel is costly.
} 
different to those that determine the supply of deposits. Moreover, changes in FX regulatory policy can also affect the strength of the correlation between these variables. ${ }^{17}$

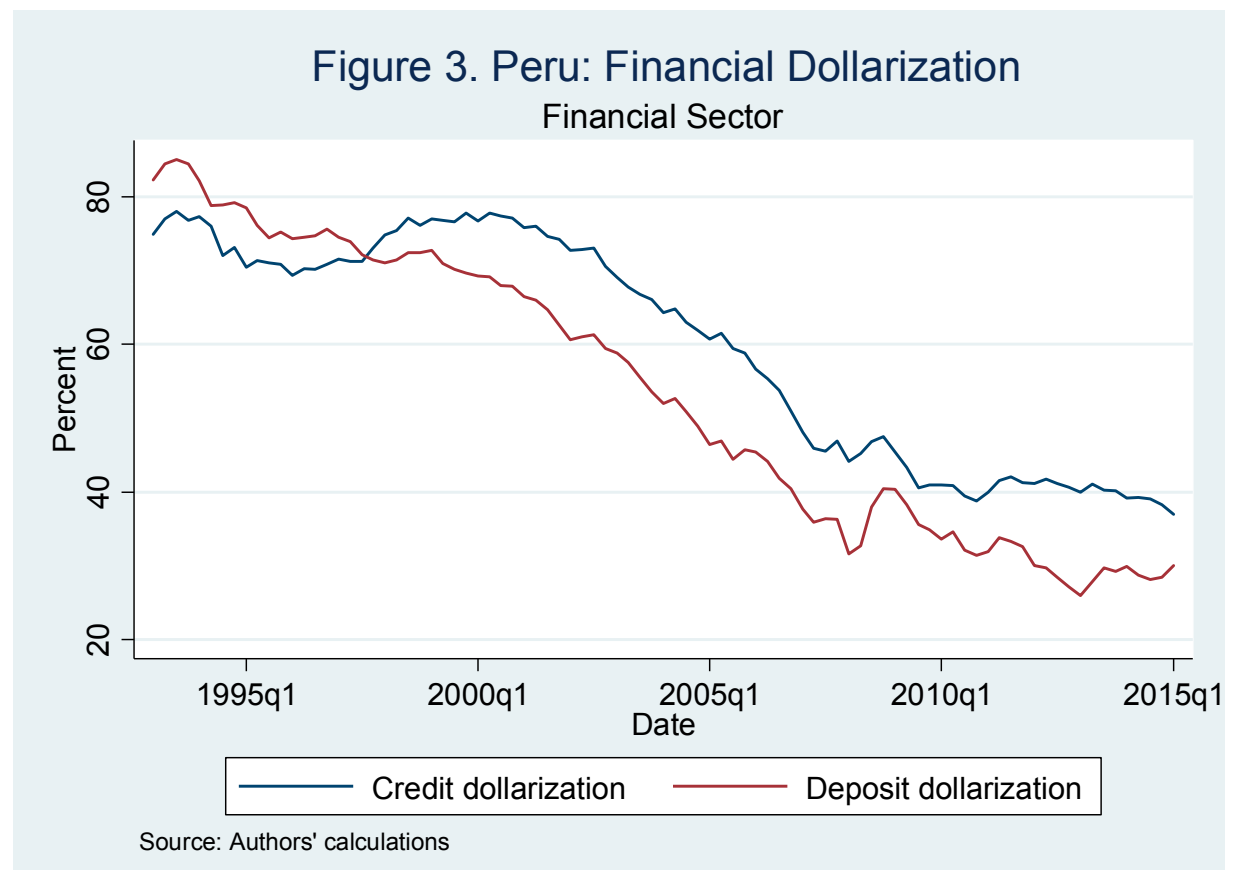

As a first step in our econometric analysis, we test for the presence of unit roots in deposit and credit dollarization ratios and cannot reject it. This is the flip-side of the dollarization persistence phenomenon noted earlier. We cannot find, however, any robust evidence of co-integration between either credit or deposit dollarization and their potential explanatory variables. On this basis, we proceed to estimate our regressions in first differences; that is, our dependent variable is the quarterly change in the dollarization ratio.

The results for credit dollarization are reported in Table 3. We start by introducing one control variable at a time, starting with the list of domestic factors in Section II-namely, the inflation targeting dummy, the higher provisions for foreign currency loans dummy, and the higher capital requirement for FX exposure dummy. ${ }^{18}$ The results in columns $1-3$ of

\footnotetext{
${ }^{17}$ In a related paper, Garcia-Escribano, 2010, also examines the drivers of the Peruvian de-dollarization experience during the 2001:M1-2009:M12 period. Both credit dollarization and deposit dollarization —in first differences - are modeled as part of a VAR model that includes other variables such as inflation and exchange rate variability, among others.

${ }^{18}$ Peru adopted inflation targeting in early 2002. The Peruvian version of IT utilizes the policy interest rate to achieve the 2 percent inflation target while using unconventional instruments to avoid excessive credit movements in a partially dollarized economy (see, for instance, Rossini et al, 2011). The central bank also intervenes in the FOREX with the objective to reduce exchange rate volatility and increase international reserves (Rossini, et. al. 2012).
} 
Table 3 are striking. There is strong evidence that inflation targeting has helped de-dollarize the Peruvian financial system. Indeed, column 3 suggests that the adoption of IT has reduced credit dollarization by over $2 \frac{1}{2}$ percentage points a year. ${ }^{19}$ The introduction of higher provisions for foreign currency loans also seems to have contributed to de-dollarize the financial system, albeit temporarily. ${ }^{20}$ In December 2014, the central bank introduced new repos in local currency aimed to encourage credit expansion in local currency and the substitution of dollar loans with local currency loans. Given that our regression sample ends in 2014:Q4, an evaluation of this policy in this study would be premature.

We next proceed by sequentially introducing the set of other relevant domestic controls, including the reserve requirements in dollar deposits, ${ }^{21}$ the expected real GDP growth (1-year ahead), and the change in the relative price of non-tradables to tradables (lagged). Columns 4-7 of Table 3 indicate that only the latter variable, as proxied by lagged changes in the real exchange rate, matter for the de-dollarization of the Peruvian financial sector. ${ }^{22}$ Indeed, one standard deviation increase in the lagged change in the real exchange (about 0.023 percent) rate is associated with a $1 / 4$ percentage point reduction in the credit dollarization ratio.

${ }^{19}$ This is $-0.716 * 4=-2.86$. Lin and Ye, 2013, using the empirical counterpart of the Ize-Yeyati portfolio dollarization model, also find that IT has significantly negative effects on financial dollarization.

${ }^{20}$ As discussed in Garcia-Escribano, 2010, this result has to be taken with a grain of salt, as the timing of the dummy coincides with other important events including a reduction in the IT band since 2007. The central bank introduced, starting in March 2013, an additional reserve requirement to discourage mortgage and vehicular dollar loans, and, starting in October 2013, extra reserve requirements to be applied to entities with dollar loan portfolios that exceed their September 2013 level (Choy and Chang, 2014).

${ }^{21}$ This policy is aimed to affect the quantities of credit. However, in non-competitive banking industries, such as the Peruvian, these policies also affect interest rate spreads (see, Catão and Terrones, 2000).

${ }^{22}$ Mendoza, 2005, reports evidence that shows that the relative non-tradable prices and the real exchange rate are tightly linked. The REER is herewith defined so that a rise means a real exchange rate appreciation. 
Table 3. Peru: Determinants of the Financial Sector Credit Dollarization (1993:Q1-2014:Q4)

\begin{tabular}{|c|c|c|c|c|c|c|c|c|c|c|c|c|}
\hline & $-1-$ & $-2-$ & $-3-$ & $-4-$ & $-5-$ & $-6-$ & $-7-$ & $-8-$ & $-9-$ & $-10-$ & $-11-$ & $-12-$ \\
\hline \multicolumn{13}{|l|}{ Domestic Factors } \\
\hline \multirow[t]{2}{*}{ Inflation targeting (dummy) } & $-0.716 * * *$ & $-0.577^{* *}$ & $-0.628 * *$ & $-0.569 *$ & $-0.630 * *$ & $-0.611^{* *}$ & $-0.586 * *$ & & & & & $-0.448 *$ \\
\hline & [0.269] & [0.268] & [0.291] & {$[0.290]$} & [0.290] & {$[0.285]$} & {$[0.278]$} & & & & & [0.237] \\
\hline \multirow[t]{2}{*}{ Higher provisions for foreign currency loans (dummy) } & & $-1.804 * * *$ & $-1.752 * * *$ & $-1.783^{* * *}$ & $-1.701 * * *$ & $-1.806 * * *$ & $-1.763 * * *$ & & & & & $-1.564 * * *$ \\
\hline & & [0.362] & [0.378] & [0.374] & [0.379] & [0.387] & [0.388] & & & & & [0.527] \\
\hline \multirow[t]{2}{*}{ Higher capital req.for foreign exchange exposure (dummy) } & & & 0.272 & 0.228 & 0.0766 & 0.228 & -0.0055 & & & & & -0.425 \\
\hline & & & [0.239] & {$[0.242]$} & {$[0.347]$} & [0.247] & [0.355] & & & & & [0.309] \\
\hline \multirow[t]{2}{*}{ Marginal reserve requirement in foreign currency (difference) } & & & & -0.035 & & & -0.0165 & & & & & 0.0354 \\
\hline & & & & {$[0.0262]$} & & & [0.0288] & & & & & [0.0217] \\
\hline \multirow[t]{2}{*}{ Real GDP growth (1-year ahead forcast) } & & & & & 0.151 & & 0.164 & & & & & $0.283^{* *}$ \\
\hline & & & & & {$[0.148]$} & & [0.153] & & & & & [0.125] \\
\hline \multirow[t]{2}{*}{ Real exchange rate (logs, lagged difference) } & & & & & & $-12.21^{* *}$ & $-12.14^{* *}$ & & & & & $-16.63 * * *$ \\
\hline & & & & & & [5.787] & [6.030] & & & & & [5.933] \\
\hline \multicolumn{13}{|l|}{ External Factors } \\
\hline \multirow[t]{2}{*}{ Metal prices (logs real, difference) } & & & & & & & & $-5.714 * * *$ & & & $-6.597 * * *$ & $-6.584 * * *$ \\
\hline & & & & & & & & [1.584] & & & [1.387] & [1.194] \\
\hline \multirow[t]{2}{*}{ Libor interest rate (3-month US, difference) } & & & & & & & & & 0.261 & & $0.653 * * *$ & $0.787 * * *$ \\
\hline & & & & & & & & & [0.283] & & [0.214] & [0.186] \\
\hline \multirow[t]{2}{*}{ VIX (logs eop, difference) } & & & & & & & & & & $1.294 * * *$ & $1.004^{* *}$ & $1.148 * * *$ \\
\hline & & & & & & & & & & {$[0.440]$} & {$[0.404]$} & [0.401] \\
\hline Observations & 88 & 88 & 88 & 88 & 88 & 88 & 88 & 88 & 88 & 88 & 88 & 88 \\
\hline R-squared & 0.148 & 0.23 & 0.234 & 0.245 & 0.245 & 0.278 & 0.295 & 0.214 & 0.0819 & 0.138 & 0.309 & 0.519 \\
\hline Adjusted R-squared & 0.107 & 0.184 & 0.177 & 0.179 & 0.179 & 0.215 & 0.213 & 0.176 & 0.0376 & 0.0967 & 0.258 & 0.443 \\
\hline
\end{tabular}

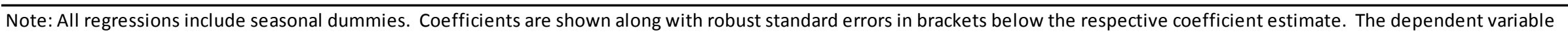
is the change in the loan dollarization ratio.

* significant at the 10 percent level, ** significant at the 5 percent level, *** significant at the 1 percent level. 
We now explore the role that external factors have played in the de-dollarization of the Peruvian financial sector. In particular, we assess the importance of changes in the real metal prices, the international interest rate, and the VIX. Columns 8-11 of Table 3 suggest that an increase in metal prices is linked to financial de-dollarization reflecting the appreciating effects that stronger metal prices have on the bilateral exchange rate (Figure 4). A standard deviation increase in the change of the log of real metal prices $(0.085)$ is associated with a reduction in the credit dollarization ratio of $1 / 2$ percentage points. This result corroborates the important role that local currency appreciation has played in the dedollarization of several Latin American countries (see, for instance, Garcia-Escribano and Sosa, 2011).

It is not surprising that as global risk aversion rises so does credit dollarization. The regression results indicate that a standard deviation increase in the first difference of the logarithm of the VIX (0.274) is associated with an over $1 / 4$ percentage point increase in the credit dollarization ratio. Perhaps somewhat surprisingly, we find that credit dollarization moves in the same direction as the changes in world interest rates. This might be a consequence of higher interest rate elasticity on the demand for dollar loans than in the demand for local currency loans.

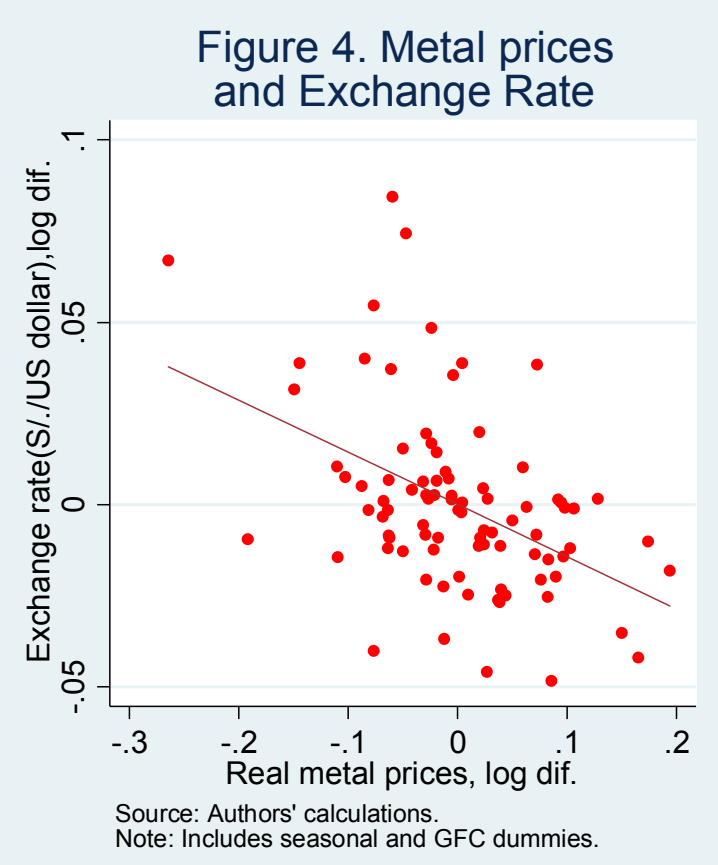

Our preferred specification is reported in column 12 of Table 3. This specification combines both the domestic and external drivers discussed earlier. While the effect of changes in the marginal reserve requirements for dollar deposits remains insignificant, all 
other factors yield plausibly signed and statistically significant coefficients. ${ }^{23}$ In particular, we find that better growth prospects are significantly associated with an increase in credit dollarization, which suggests that the earlier specifications had omitted important controls. A $\mathrm{R}^{2}$ of a little over 50 percent indicates that our empirical model does a fair job in explaining quarterly changes in loan dollarization.

The results for deposit dollarization are reported in Table 4. The sign and statistical significance of the estimated coefficients are broadly similar to that of credit dollarization, except that marginal reserve requirement on dollar deposits now appears to discourage dollarization in most specifications, and the IT dummy is no longer statistically significant.

Why isn't IT effective in de-dollarizing financial system deposits? While this surprising result clearly deserves further research, we conjecture that banks are more sensitive than depositors to inflation risks when deciding to allocate their assets between local currency loans and dollar loans. Moreover, depositors might be more easily allured by higher local currency interest rates when inflation is more volatile. This is a particularly plausible explanation the larger the maturity gap between loans and deposits, i.e., the lower the average time maturity of deposits vis-à-vis loans. The fact that changes in the marginal reserve requirement in dollar deposits help reduce deposit dollarization but not credit dollarization suggests that these unconventional policies should be used as part of a "package" that also includes measures that penalizes other sources of dollar funding by banks (including short-term debt).

Table 5 further probes into the robustness of the above results, examining what exchange rate volatility and domestic and foreign inflation volatility do to dollarization. Portfolio theory has emphasized the role of these variables as important drivers of dollarization. We compute such volatilities as three-month non-overlapping standard deviations of the change in these variables. The last two rows on the top of Table 5 show the results for the nominal exchange rate and domestic CPI inflation volatility. None of these variables is economically or statistically significant in explaining either credit or deposit dollarization. There is some evidence, however, that U.S. inflation volatility discourages credit dollarization, as shown in the last row of Table 5. This finding, however, is not robust across specifications and does not hold for deposit dollarization.

\footnotetext{
${ }^{23}$ Again, one might question the positive coefficient on the Libor interest rate, but as per the discussion in Section II, this coefficient is ambiguously signed in theory. Another ambiguously signed coefficient is expected real GDP growth. To the extent that it increases the demand for dollar loans more than for local currency loans, it can increase dollarization.
} 
Table 4. Peru: Determinants of the Financial Sector Deposit Dollarization (1993:Q1-2014:Q4)

\begin{tabular}{|c|c|c|c|c|c|c|c|c|c|c|c|c|}
\hline & $-1-$ & $-2-$ & $-3-$ & $-4-$ & $-5-$ & $-6-$ & $-7-$ & $-8-$ & $-9-$ & $-10-$ & $-11-$ & $-12-$ \\
\hline \multicolumn{13}{|l|}{ Domestic Factors } \\
\hline \multirow[t]{2}{*}{ Inflation targeting (dummy) } & -0.18 & -0.0621 & -0.182 & -0.0142 & -0.182 & -0.163 & -0.015 & & & & & 0.167 \\
\hline & [0.313] & [0.323] & [0.353] & [0.337] & [0.354] & [0.345] & {$[0.332]$} & & & & & [0.290] \\
\hline \multirow[t]{2}{*}{ Higher provisions for foreign currency loans (dummy) } & & $-1.533^{* * *}$ & $-1.412^{* * *}$ & $-1.498 * * *$ & $-1.430 * * *$ & $-1.475 * * *$ & $-1.566 * * *$ & & & & & $-1.290 * *$ \\
\hline & & [0.290] & [0.324] & [0.330] & [0.306] & [0.328] & [0.321] & & & & & [0.532] \\
\hline \multirow[t]{2}{*}{ Higher capital req.for foreign exchange exposure (dummy) } & & & 0.642 & 0.515 & 0.707 & 0.59 & 0.592 & & & & & 0.081 \\
\hline & & & {$[0.506]$} & [0.463] & [0.623] & [0.492] & [0.574] & & & & & [0.518] \\
\hline \multirow[t]{2}{*}{ Marginal reserve requirement in foreign currency (difference) } & & & & $0.0990 * * *$ & & & $-0.0890^{* *}$ & & & & & -0.0222 \\
\hline & & & & [0.0341] & & & [0.0393] & & & & & [0.0348] \\
\hline \multirow[t]{2}{*}{ Real GDP growth (1-year ahead forcast) } & & & & & -0.0501 & & -0.0806 & & & & & 0.0487 \\
\hline & & & & & [0.193] & & {$[0.200]$} & & & & & [0.172] \\
\hline \multirow[t]{2}{*}{ Real exchange rate (logs, lagged difference) } & & & & & & $-14.41 *$ & -11.18 & & & & & $-17.15^{* *}$ \\
\hline & & & & & & [7.972] & [8.161] & & & & & [7.146] \\
\hline \multicolumn{13}{|l|}{ External Factors } \\
\hline \multirow[t]{2}{*}{ Metal prices (logs real, difference) } & & & & & & & & $-7.706 * * *$ & & & $-8.906 * * *$ & $-8.812^{* * *}$ \\
\hline & & & & & & & & [1.522] & & & [1.562] & [1.848] \\
\hline \multirow[t]{2}{*}{ Libor interest rate (3-month US, difference) } & & & & & & & & & 0.353 & & $0.882^{* * *}$ & $0.892^{* * *}$ \\
\hline & & & & & & & & & {$[0.460]$} & & [0.333] & [0.330] \\
\hline \multirow[t]{2}{*}{ VIX (logs eop, difference) } & & & & & & & & & & $1.732 * * *$ & $1.341^{* *}$ & $1.318^{* *}$ \\
\hline & & & & & & & & & & [0.559] & {$[0.527]$} & {$[0.570]$} \\
\hline Observations & 88 & 88 & 88 & 88 & 88 & 88 & 88 & 88 & 88 & 88 & 88 & 88 \\
\hline R-squared & 0.0373 & 0.0813 & 0.0965 & 0.161 & 0.0973 & 0.142 & 0.191 & 0.223 & 0.0461 & 0.12 & 0.35 & 0.455 \\
\hline Adjusted R-squared & -0.00914 & 0.0252 & 0.0295 & 0.0874 & 0.0183 & 0.0666 & 0.0974 & 0.185 & 0.000111 & 0.0778 & 0.302 & 0.367 \\
\hline
\end{tabular}

Note: All regressions include seasonal dummies. Coefficients are shown along with robust standard errors in brackets below the respective coefficient estimate. The dependent variable is the change in the deposit dollarization ratio.

${ }^{*}$ significant at the 10 percent level, ${ }^{* *}$ significant at the 5 percent level, *** significant at the 1 percent level. 
Table 5. Peru: Determinants of the Financial Sector Dollarization--Additional Variables (1993:Q1-2014:Q4)

\begin{tabular}{|c|c|c|c|c|c|c|c|c|c|c|}
\hline & \multicolumn{5}{|c|}{ Credit } & \multicolumn{5}{|c|}{ Deposit } \\
\hline & $-1-$ & $-2-$ & $-3-$ & $-4-$ & $-5-$ & $-6-$ & $-7-$ & $-8-$ & $-9-$ & $-10-$ \\
\hline \multicolumn{11}{|l|}{ Domestic Factors } \\
\hline \multirow[t]{2}{*}{ Inflation targeting (dummy) } & $-0.586^{* *}$ & $-0.576 * *$ & & & $-0.433^{*}$ & -0.015 & -0.00736 & & & 0.165 \\
\hline & [0.278] & [0.284] & & & [0.239] & [0.332] & [0.341] & & & [0.293] \\
\hline \multirow[t]{2}{*}{ Higher provisions for foreign currency loans (dummy) } & $-1.763^{* * *}$ & $-1.799 * * *$ & & & $-1.612^{* * *}$ & $-1.566 * * *$ & $-1.595 * * *$ & & & $-1.302 * *$ \\
\hline & [0.388] & [0.353] & & & [0.513] & [0.321] & [0.398] & & & {$[0.566]$} \\
\hline \multirow[t]{2}{*}{ Higher capital req.for foreign exchange exposure (dummy) } & -0.0055 & -0.0131 & & & -0.436 & 0.592 & 0.586 & & & 0.0914 \\
\hline & {$[0.355]$} & [0.344] & & & {$[0.323]$} & [0.574] & {$[0.565]$} & & & [0.517] \\
\hline \multirow[t]{2}{*}{ Marginal reserve requirement in foreign currency (difference) } & -0.0165 & 0.162 & & & $0.274^{* *}$ & $-0.0890 * *$ & -0.0841 & & & 0.0425 \\
\hline & [0.0288] & [0.155] & & & [0.129] & [0.0393] & [0.194] & & & [0.168] \\
\hline \multirow[t]{2}{*}{ Real GDP growth (1-year ahead forcast) } & 0.164 & -0.0234 & & & 0.0252 & -0.0806 & $-0.0998 * *$ & & & -0.027 \\
\hline & [0.153] & [0.0314] & & & [0.0206] & {$[0.200]$} & [0.0407] & & & [0.0341] \\
\hline \multirow[t]{2}{*}{ Real exchange rate (logs, lagged difference) } & $-12.14^{* *}$ & $-11.86^{*}$ & & & $-16.86 * * *$ & -11.18 & -10.84 & & & $-16.98^{* *}$ \\
\hline & {$[6.030]$} & {$[6.333]$} & & & [6.114] & [8.161] & [8.637] & & & [7.518] \\
\hline \multirow[t]{2}{*}{ Inflation Volatility (logs, difference) } & & -0.135 & & & -0.0755 & & -0.187 & & & -0.0583 \\
\hline & & [0.135] & & & {$[0.113]$} & & {$[0.265]$} & & & [0.183] \\
\hline \multirow[t]{2}{*}{ Exchange rate volatility (logs, difference) } & & 0.0299 & & & -0.0165 & & 0.107 & & & 0.0539 \\
\hline & & [0.130] & & & {$[0.108]$} & & [0.189] & & & [0.167] \\
\hline \multicolumn{11}{|l|}{ External Factors } \\
\hline \multirow[t]{2}{*}{ Metal prices (logs real, difference) } & & & $-6.597 * * *$ & $-6.571 * * *$ & $-6.347^{* * *}$ & & & $-8.906 * * *$ & $-8.913 * * *$ & $-8.636 * * *$ \\
\hline & & & [1.387] & [1.393] & [1.288] & & & [1.562] & [1.571] & [1.766] \\
\hline \multirow[t]{2}{*}{ Libor interest rate (3-month US, difference) } & & & $0.653 * * *$ & $0.660^{* * *}$ & $0.758 * * *$ & & & $0.882^{* * *}$ & $0.880^{* *}$ & $0.855^{* * *}$ \\
\hline & & & [0.214] & [0.207] & [0.192] & & & [0.333] & {$[0.335]$} & [0.300] \\
\hline \multirow[t]{2}{*}{ VIX (logs eop, difference) } & & & $1.004^{* *}$ & $0.810^{*}$ & $0.910^{* *}$ & & & $1.341^{* *}$ & $1.394^{* *}$ & $1.321^{*}$ \\
\hline & & & [0.404] & {$[0.428]$} & [0.423] & & & [0.527] & {$[0.593]$} & {$[0.663]$} \\
\hline \multirow[t]{2}{*}{ US inflation Volatility (logs, difference) } & & & & -0.119 & $-0.146^{* *}$ & & & & 0.0324 & -0.00698 \\
\hline & & & & [0.0852] & [0.0621] & & & & [0.0860] & {$[0.0730]$} \\
\hline Observations & 88 & 88 & 88 & 88 & 88 & 88 & 88 & 88 & 88 & 88 \\
\hline R-squared & 0.295 & 0.305 & 0.309 & 0.324 & 0.54 & 0.191 & 0.208 & 0.35 & 0.351 & 0.457 \\
\hline Adjusted R-squared & 0.213 & 0.204 & 0.258 & 0.265 & 0.445 & 0.0974 & 0.0937 & 0.302 & 0.294 & 0.344 \\
\hline
\end{tabular}

Note: All regressions include seasonal dummies. Coefficients are shown along with robust standard errors in brackets below the respective coefficient estimate. The dependent variable is the change in the loan dollarization ratio (or the change in the deposit dollarization ratio).

* significant at the 10 percent level, ${ }^{* *}$ significant at the 5 percent level, ${ }^{* * *}$ significant at the 1 percent level. 


\section{CONCLusion}

We have presented new evidence of financial de-dollarization across a broad range of emerging market economies in the years preceding the global financial crisis and documented that this process stalled in recent years in many — but not all-EMEs. This is an indication that dollarization persistence is not synonymous of dollarization irreversibility. Indeed, after a partial and short-lived reversal in 2008-09, the trend towards de-dollarization has continued in some highly dollarized emerging economies, like Peru. But in some lowerdollarized emerging economies, dollarization has increased over the past five years, albeit mildly. Overall, the broad cross-country evidence suggests that de-dollarization has been shaped by a combination of domestic and global factors.

We zoom in on such inter-play of domestic and external factors by looking at the experience of Peru. Our findings indicate that de-dollarization can be achieved through sound macroeconomic policies and some macro-prudential measures. The strongest domestic factor behind credit de-dollarization seems to have been the introduction of inflation targeting in 2002. This policy has been underpinned by a conservative fiscal stance that has halved public debt since 2002, yielding the country an investment grade and spurring confidence in domestic macroeconomic management. This has contributed to the development of the domestic debt market — both public and private — which has, in turn, improved public debt profile and its management. Future research should examine how inflation targeting has affected the extent of financial dollarization in other emerging market economies.

External factors reinforced this process on three fronts. First, lower international interest rates lowered the cost of foreign borrowing at the expense of capturing domestic deposits, so loan dollarization fell. As a result borrowing abroad has risen, including from the corporate non-financial sector. Second, the decline in the volatility of global stock markets in the years before the GFC and from 2010 onwards have weakened the flight-to-safety effect, further contributing to financial de-dollarization. Third, higher commodity prices in the 2000-2007 and some recovery after the GFS also helped de-dollarization by appreciating the local currency.

A main policy implication is that being open to global factors helps de-dollarization when international liquidity is abundant, commodity prices are strong, and global volatility is low. A less dependable way to achieve de-dollarization is through macro-prudential regulations - especially through higher loan provisioning and higher capital requirements on dollar loans - and the introduction of inflation targeting cum supportive fiscal policies. Of the two, the first has the clear downside of taxing financial intermediation and might backfire if all sources of bank financing are not equally affected. Thus, credible macroeconomic policies combined with inflation targeting emerge as the most effective way to de-dollarize an economy. The experience of Peru illustrates that these policies can be rather effective when combined with favorable external conditions, even in countries that are highly dollarized to begin with. 
APPENDiX

\section{A. List of EMEs in the Cross-Country Sample}

The sample of countries we have utilized in section II comprises twenty eight emerging market economies, which have been grouped in three regions ${ }^{24}$ : Latin America (Argentina, Chile, Costa Rica, Dominican Republic, Guatemala, Mexico, Paraguay, Peru, Uruguay, and Venezuela), Europe (Turkey, Ukraine, Czech Republic, Slovak Republic, Serbia, Hungary, Croatia, Slovenia, Poland, and Romania), and Asia and other (South Africa, Israel, Egypt, Indonesia, Korea, Malaysia, Pakistan, and Thailand).

\section{B. Data Sources of the Peruvian Database}

B. Data Sources of the Peruvian Database.

\begin{tabular}{|c|c|c|}
\hline Variable & Source & Comment \\
\hline \multicolumn{3}{|l|}{ 1. Dummy variables } \\
\hline Inflation targeting & Central Bank of Peru & $\begin{array}{l}\text { Takes on the value of one from 2002:Q1 and } \\
\text { zero otherwise. }\end{array}$ \\
\hline Higher provisions for $\mathrm{FC}$ loans & Garcia-Escribano, M. , 2010. & $\begin{array}{l}\text { Takes on the value of one during 2006:Q3- } \\
\text { 2007:Q2 and zero otherwise. }\end{array}$ \\
\hline Higher capital requirement for FX exposure & Choy, M. and G. Chang , 2014 & $\begin{array}{l}\text { Takes on the value of one from 2012:Q4 and } \\
\text { zero otherwise. }\end{array}$ \\
\hline \multicolumn{3}{|l|}{ 2. Other variables } \\
\hline Libor rates on US dollar deposits (3-months) & IFS & \\
\hline $\mathrm{CPI}$ & IFS & For Peru and the United States \\
\hline Metal price index & IMF commodity prices & \\
\hline Real GDP growth (1-year forecast) & Consensus forecast/WEO & \\
\hline VIX & FRED & CBOE Volatility Index \\
\hline Real effective exchange rate. & IMF & \\
\hline Reserve requirement in dollar deposits (marginal) & Central Bank of Peru & \\
\hline Bilateral exchange rate (Soles per Dollar, Average) & Central Bank of Peru & Interbank exchange rate. \\
\hline Credit of financial system to private sector: foreign currency & Central Bank of Peru & \\
\hline Credit of financial system to private sector: total & Central Bank of Peru & Credit to the private sector \\
\hline Liquidity of financial system: foreign currency & Central Bank of Peru & \\
\hline Quasimoney of financial system: local currency & Central Bank of Peru & \\
\hline
\end{tabular}

${ }^{24}$ Some countries such as Brazil, Colombia, and Ecuador have been eliminated from the sample as they do not allow for deposits in foreign currency or the deposits are fully dollarized. In addition, Latvia and Lithuania have been dropped from the sample as data is available for eight or less years. 


\section{REFERENCES}

Antinolfi, G., C. Landeo and M. Nikitin. 2007. "Dollarization and the Inflation Threshold." The Canadian Journal of Economics 40: 628-649.

Bloom, N., A. Kose, and M.E. Terrones. 2013. "Held Back by Uncertainty." Finance and Development 50: 38-41.

Broda, C. and E. Levy Yeyati. 2006. "Endogenous Deposit Dollarization.” Journal of Money, Credit and Banking 38 (4): 963-988.

Calvo, G. and C. Vegh. 1996. "From Currency Substitution to Dollarization and Beyond: Analytical and Policy Issues." In G. Calvo (ed.) Money, Exchange Rates and Output. MIT Press.

Catão, L.A.V. and M.E. Terrones. 2000. "Determinants of Dollarization: The Banking Side." IMF Working Paper 00/146.

Catão, L.A.V. and M.E. Terrones. 2005. "Fiscal Deficits and Inflation.” Journal of Monetary Economics 52: 529-54.

Choy, M. y G. Chang. 2014. "Medidas Macroprudenciales Aplicadas en el Perú.” Banco Central del Perú, DT No. 2014-007.

De Nicolo, G., P. Honohan, and A. Ize, 2005. "Dollarization of the Bank Deposits: Causes and Consequences." Journal of Banking and Finance, Vol. 29, pp. 16971727.

Edwards, S. 2006 "The Relationship between Exchange Rates and Inflation Targeting Revisited." NBER Working Paper 12163.

Garcia-Escribano, M. 2010. “Peru: Drivers of De-dollarization.” IMF Working Paper $10 / 169$.

Garcia-Escribano, M. and S. Sosa. 2011. "What is Driving De-Dollarization in Latin America?" IMF Working Paper 11/10.

Guidotti, P. and C. Rodriguez. 1992. "Dollarization in Latin America." IMF Staff Papers 39: $518-544$.

Gulde, A., D. Hoelscher, A. Ize, D. Marston, and G. De Nicolo. 2004. "Financial Stability in Dollarized Economies." IMF Occassional Paper 230.

Honohan, P. 2008. “The Retreat of Deposit Dollarization.” International Finance 11 (3): 247-268. 
IMF. 2005. "Does Inflation Targeting Work in Emerging Markets?” World Economic Outlook, September, Chapter 4.

Lane, P. and P. McQuade. 2013. "Domestic Credit Growth and International Capital Flows." Scandinavian Journal of Economics 116: 218-252.

Levy Yeyati, E. 2006. “Financial Dollarization.” Economic Policy: 62-118.

Lin, S. and H. Ye. 2013. "Does Inflation Targeting Help Reduce Financial Dollarization?" Journal of Money, Credit and Banking 45 (7): 1253-1274.

Mendoza, E. 2005. "Real Exchange Rate Volatility and the Price of Nontradable Goods in Economies Prone to Sudden Stops." Economia: 103-148.

Mendoza, E. and M.E. Terrones. 2014. “An Anatomy of Credit Booms and their Demise.” Published in M. Fuentes, M., C. Raddatz, and Reinhart, C. (eds.), Capital Mobility and Monetary Policy. 2014. Central Bank of Chile, Volume 18.

Mishkin, F. and K. Schmidt-Hebbel. 2007. "Does Inflation Targeting Make a Difference?" NBER Working Paper 12876

Phillips, S., L.A.V.Catão, L.Ricci et al. 2013. External Balance Assessment (EBA) Methodology. IMF Working Paper 13/272

Rajan, R. and I. Totkatlidis. 2005. "Dollar Shortages and Crises." International Journal of Central Banking, September: 177-220.

Rappoport, V. 2009. "Persistence of Dollarization After Price Stabilization." Journal of Monetary Economics 56: 979-989.

Reinhart, C. and G. Calvo. 2001. "Reflections on Dollarization.” MPRA Paper No. 8206.

Rojas-Suarez, L. 1992. “Currency Substitution and Inflation in Peru.” IMF Working Paper $92 / 33$.

Rossini, R., Z. Quispe, and D. Rodriguez. 2011. "Capital Flows, Monetary Policy and FOREX Interventions in Peru.” Central Reserve Bank of Peru, DT No. 2011008.

Rossini, R., Z. Quispe, and J. Loyola. 2012. "Fiscal Policy Considerations in the Design of Monetary Policy in Peru.” Central Reserve Bank of Peru, DT No. 2012-022.

Savastano, M. 1996. "Dollarization in Latin America: Recent Evidence and Some Policy Issues.” IMF Working Paper 96/4. 
Tornell, A. and F. Westermann. 2005. Boom-Bust Cycles and Financial Liberalization, MIT Press.

Winkelried, D. and P. Castillo. 2010. "Dollarization Persistence and Individual

Heterogeneity.” Journal of International Money and Finance 29: 1596-1618. 